Ethiopian Journal of Environmental Studies \& Management 9(Suppl. 2): 1036 - 1046, 2016. ISSN:1998-0507 doi: http://dx.doi.org/10.4314/ejesm.v9i2.9S

Submitted: September 07, 2016

Accepted: December 16, 2016

\title{
ASSESSMENT AND BIOREMEDIATION OF HEAVY METALS FROM CRUDE OIL CONTAMINATED SOIL BY EARTHWORMS
}

*EKPERUSI, O.A., AIGBODION, I.F., ILOBA, B.N. AND OKOREFE, S.

Environmental Quality Management programme, Department of Animal and

Environmental Biology, Faculty of Life Sciences, University of Benin, Benin City, Nigeria

\begin{abstract}
The assessment of the levels of heavy metals present in crude oil contaminated soil and the application of the earthworm - Hyperiodrilus africanus with interest on the bioremediation of metals from the contaminated soil was investigated within a 90-days period under laboratory conditions. Selected heavy metals such as zinc, manganese, copper, nickel, cadmium, vanadium, chromium, lead, mercury and arsenic were determined using AAS. The physicochemical conditions showed an increase in $\mathrm{pH}$, but a decrease in conductivity, total nitrogen and chloride. Assessment of heavy metals indicated that heavy metals are present in crude oil at elevated levels beyond national regulatory guidelines. There was a significant $(P<0.05)$ decreasing trend in percentage of heavy metals present in soil after inoculation with earthworm in zinc (57.66\%), manganese (57.72\%), copper (57.64\%), nickel (57.69\%), cadmium (57.57\%), vanadium (57.68\%), chromium (57.67\%), lead (57.64\%), arsenic (1.36\%) and mercury (57.41\%) after 90 days period. Bioaccumulation factor showed that zinc, manganese, copper, cadmium, vanadium, chromium and lead had a factor of 1.36, while nickel, arsenic and mercury had 1.37, 0.01 and 1.35 respectively. The results showed that the earthworms $H$. africanus can be effectively used to bioremediate heavy metals from crude oil polluted soil.
\end{abstract}

Key Words: Heavy metals, Bioremediation, Vermiremediation, Crude oil, Hyperiodrilus africanus

\section{Introduction}

Crude oil extracted from oil fields may have a considerable amount of heavy metals as part of the impurities present. This is largely dependent on the mineral bearing rocks where the crude oil was formed. These impurities are only removed to some extent during cracking and refining of petroleum into various products. During oil spill, such heavy metals are bound to soil with large chain hydrocarbon compounds after volatile constituents of the oil have vapourized into the atmosphere. In the remediation of contaminated soil, much attention is given to the petroleum hydrocarbons and other related compounds while less or none is given to the associated heavy metals in such contaminated environment.

Heavy metals due to their nonbiodegradable nature can remain bound in soil for a long time, can bioaccumulate into soil biota, leached into underground water and pose a considerable threat to the environment, biodiversity and public health (Ekperusi and Aigbodion, 2015). 
Earthworms are vital components of soil fauna. They are known to be found at the base of the food chain among soil biota and are key organisms in determining soil function and health (Edwards and Arancon, 2006).

Research on earthworms' potentials to bioaccumulate and biodegrade a wide range of pollutants including heavy metals from polluted environment (Satchell 1983; Schaefer and Filser 2007; Sinha et al., 2008; Ameh, 2013) are available. Hartenstein et al. (1980) reported that earthworms can bioaccumulate high concentrations of heavy metals like cadmium, mercury, lead, copper, manganese, calcium, iron and zinc in their tissues without affecting their physiology and this particularly when the metals are mostly non-bioavailable. Cheng and Wong (2002) found an increase in zinc availability in a loamy soil after 40 days incubation with an anecic Pheretima sp. In contrast, Zorn et al. (2004) found a decrease in zinc availability in a sandy soil after 175 days incubation with endogeic Aporrectodea caliginosa, but no effect on zinc availability in the presence of endogeic Allolobophora chlorotica. In a similar trend ContrerasRamos et al. (2006) confirmed that the earthworms reduced the concentrations of chromium, copper, zinc and lead in the vermicomposted sludge below the limits set by the United States Environmental Protection Agency in 60 days. Ameh et al. (2012) reported a decrease on the concentration of zinc, copper, nickel and chromium exposed to used engine oil-contaminated soil with Eudrilus eugenia.

Some researchers has reported that bioaccumulation of heavy metals by earthworms is metal-specific (Marinussen et al., 1997), as well as earthworm species-specific (Morgan and Morgan, 1999; Hobbelen et al., 2006; Suthar et al., 2008). However, the difference in metal uptake and elimination kinetics between earthworm species is still unknown. Peijnenburg et al. (1999) reported that metal uptake and elimination were both metal and species-dependent. Worms typically attained steady-state concentrations rapidly for chromium, copper, nickel and zinc using Eisenia andrei. Lui (2012) reported pronounced differences on earthworms' uptake and elimination kinetics between zinc and cadmium in two physiological contrasting earthworm species (Eisenia foetida and Lumbricus terrestris) reared in three field-contaminated soils within 30 days.

Studies on the assessment of the levels of heavy metals in crude oil polluted environment are vital in order for environmental managers and scientist to device appropriate protocol for a comprehensive remediation in hydrocarbon polluted soil.

\section{Materials and Methods Experimental Design}

The crude oil for the study was obtained with permission from an offshore drilling platform in Escravos, Delta State. It has an API of 33.51 and specific gravity of 0.86 qualifying the oil blend as light crude. Soil for the experiment was prepared according to ISO standard 11268-1 (ISO, 1993) into replicates and then contaminated with $5 \mathrm{ml}$ each of crude oil and allowed to stand for 7 days. 5 gram of cow dung (additive nutrient) was thoroughly mixed with the soil and was then inoculated with ten earthworms ( $H$. africanus) into three replicates and control without earthworms. The setup was monitored regularly and water was added to maintain the moisture contents of the media for a 90 days period. A 
non-contaminated soil (NCS) was maintained all through the experiment for comparison of the background levels in the course of the study.

\section{Laboratory Analyses}

Samples from the non-contaminated soil, contaminated soil with earthworms and control without earthworm were taken to the laboratory for analyses. Physicochemical parameters such as $\mathrm{pH}$, conductivity, total nitrogen, and chloride and soil properties were determined using procedures described by AOAC (2005). Heavy metals such as zinc, manganese, copper, nickel, cadmium, vanadium, chromium, lead, arsenic and mercury were determined using Atomic Absorption Spectrophotometer (AAS) as described by Miroslav and Vladimir, (1999).

\section{Statistical Analysis}

Statistical analysis was carried out using SPSS version 21 by IBM Inc. The

Table 1: Physicochemical parameters of soil before and after contamination (Mean \pm S.E.)

\begin{tabular}{llllll}
\hline Parameters & NCS & 0 Day & 90 days & Control & Significance level \\
\hline $\mathrm{pH}$ & $5.85 \pm 0.00$ & $5.39 \pm 0.01$ & $5.60 \pm 0.03$ & $5.41 \pm 0.01$ & $\mathrm{~F}=130.71, \mathrm{P}<0.05$ \\
EC (uS/cm) & $56.00 \pm 0.00$ & $982.00 \pm 1.16$ & $415.67 \pm 3.53$ & $927.00 \pm 1.16$ & $\mathrm{~F}=13961.84, \mathrm{P}<0.05$ \\
Nitrogen $(\%)$ & $0.13 \pm 0.00$ & $0.17 \pm 0.01$ & $0.08 \pm 0.03$ & $0.16 \pm 0.01$ & $\mathrm{~F}=5.48, \mathrm{P}<0.05$ \\
Sand $(\%)$ & $96.00 \pm 0.00$ & $92.00 \pm 0.58$ & $90.07 \pm 1.10$ & $84.51 \pm 0.00$ & $\mathrm{~F}=35.52, \mathrm{P}<0.05$ \\
Silt $(\%)$ & $3.00 \pm 0.00$ & $7.00 \pm 0.58$ & $5.32 \pm 0.50$ & $5.63 \pm 0.01$ & $\mathrm{~F}=16.10, \mathrm{P}<0.05$ \\
Clay $(\%)$ & $1.00 \pm 0.00$ & $1.00 \pm 0.00$ & $3.95 \pm 0.14$ & $3.76 \pm 0.01$ & $\mathrm{~F}=11.03, \mathrm{P}<0.05$ \\
$\mathrm{Cl}^{-}(\mathrm{mg} / \mathrm{kg})$ & $16.80 \pm 0.00$ & $19.64 \pm 0.01$ & $8.31 \pm 0.07$ & $17.60 \pm 0.06$ & $\mathrm{~F}=4279.24, \mathrm{P}<0.05$ \\
\hline
\end{tabular}

$* \mathrm{NCS}=$ Non-contaminated soil, $\mathrm{P}<0.05=$ significant

$\mathrm{pH}$ of soil is essential in regulating the conditions of soil flora and fauna (Ekperusi and Aigbodion, 2015). Initial $\mathrm{pH}$ of soil was $5.85 \pm 0.00$, it decreased after contamination to $5.39 \pm 0.01$ and increased after inoculation with $H$. africanus to $5.60 \pm 0.03$ within 90 days. It is expected that the activities of earthworms in soil regulates the $\mathrm{pH}$ towards neutrality, this can be the case in a composting soil, but may be difficult to results were presented as means, standard errors and percentages while one way analysis of variance (ANOVA) was used to compare the means at $\mathrm{p}<$ 0.05. Post Hoc Duncan Multiple Range test was used to separate the means.

\section{Results and Discussion}

In this study on the assessment and bioremediation of heavy metals by $H$. africanus from soil contaminated with crude oil has shown that earthworm activities was able to significantly reduces the heavy metals concentration present in contaminated soil after 90 days of the study.

\section{Physicochemical Conditions of Soil}

The variation in the physicochemical conditions of the noncontaminated, contaminated soil with crude oil inoculated with $H$. africanus and the control without earthworm are shown in Table 1. achieve in a polluted soil since biological processes in earthworms could be divided towards several competing pathways or mechanisms for soil chemical regulation, pollutants bioaccumulation, immobilization and bioremediation. Edwards and Arancon (2006) indicated that optimal conditions of $\mathrm{pH}$ for earthworms ranges between $>5$ to $>9$. Since the $\mathrm{pH}$ was within tolerable range as reported by Owa et al. (2003) 
for earthworms in this ecological zone, the earthworm was able to carry out its function under such $\mathrm{pH}$ conditions. On the other hand, the activities of earthworms may lead to the buffering of $\mathrm{pH}$ for the survival of the species in polluted soil. Sandor and Schrader (2012) and Azarpira et al. (2013) reported higher $\mathrm{pH}$ values at the end of their experiments compared to the initial start value, but Heine and Larink (1993) reported that the $\mathrm{pH}$ of soil materials decreased during gut passage in $L$. terrestris.

Physicochemical parameters such as conductivity, total nitrogen and chloride in soil $(982.00 \pm 1.16,0.17 \pm 0.01$ and $19.64 \pm 0.01)$ increased significantly after contamination of soil compared to noncontaminated soil and decreased significantly after inoculation with earthworms $(415.67 \pm 3.53, \quad 0.08 \pm 0.03$ and 8.31 \pm 0.07 ), except for the control, (Table 1). It is usual that as bioremediation activities takes place in the contaminated soil with earthworms, the physicochemical conditions of the soil was being restored as observed in the declining trend. This is the case with report by Ceccanti et al. (2006) and Ekperusi and Aigbodion (2015). Conductivity of soil highly increased after contamination of soil and decreased with the activities of earthworms, while there was a slight decrease in the control soil at the end of the study. A similar decreasing trend was reported by Manyuchi et al. (2013). According to Bruce and Rayment (1982) the rating for nitrogen in soil ranges from $<0.05$ (very low), $0.05-0.15$ (low), $0.15-0.25$ (medium), $0.25-0.50$ (high) and $>0.5$ (very high). In this experiment the nitrogen in the non-contaminated soil could be classified as low $(0.13 \pm 0.00)$. After contamination, nitrogen values in soil increased and later decreased below the background levels at the end of the study due to the activities of earthworms as against the control soil. Several reports (Dai et al., 2004; Iordache and Borza, 2010; Ameh et al., 2011; ZavalaCruz et al., 2013) has indicated that the earthworm activities increased the nitrogen, phosphorus and potassium in composting soil. This is unlikely the case in our study. Being in a polluted environment unlike organic compost, the available nitrogen maybe needed in the bioremediation process by the earthworm in order to adapt or regulates its normal body functions in the presence of the pollutants such as the heavy metals and crude oil. Ceccanti et al. (2006) reported that the total nitrogen in organic treatments were higher and remained quite unchanged, meaning that the compost and earthworm casting regularly released nitrogen compounds.

\section{Assessment of Heavy Metals Concentration in Soil}

Prior to contamination of soil, zinc, manganese, copper, nickel and chromium were present in varying concentration while cadmium, vanadium, lead, mercury and arsenic were below detection limit $(<0.00 \pm 0.00)$. After contamination of soil with crude oil, the heavy metals concentration increased significantly from the initial or backgrounds levels. Zinc, manganese, copper, nickel and chromium increased from $0.62 \pm 0.00$ to $20.62 \pm 0.01 \mathrm{mg} / \mathrm{kg}$, $0.34 \pm 0.00$ to $8.94 \pm 0.02 \mathrm{mg} / \mathrm{kg}, 0.50 \pm 0.00$ to $\quad 6.87 \pm 0.00 \mathrm{mg} / \mathrm{kg}, \quad 0.23 \pm 0.00$ to $10.81 \pm 0.00, \quad 0.30 \pm 0.00$ to $8.15 \pm 0.01$ respectively while cadmium, vanadium, lead, mercury and arsenic in contaminated soil are $3.04 \pm 0.01 \mathrm{mg} / \mathrm{kg}$, $5.60 \pm 0.00 \mathrm{mg} / \mathrm{kg}, \quad 4.91 \pm 0.00 \mathrm{mg} / \mathrm{kg}$, $1.08 \pm 0.01 \mathrm{mg} / \mathrm{kg}$ and $2.95 \pm 0.01$ respectively. 


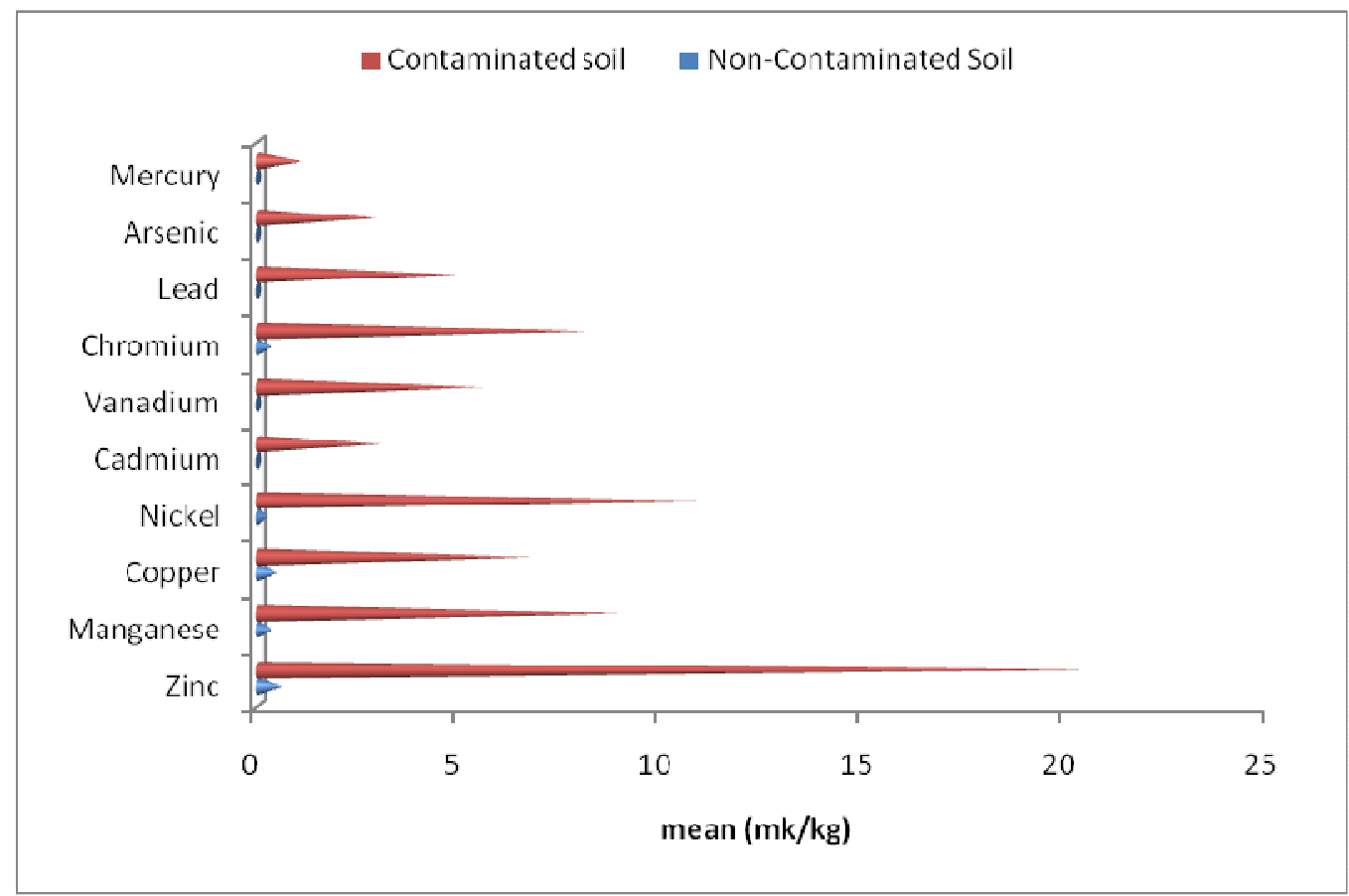

Figure 2: Heavy metals in soil before and after contamination of soil with crude oil

Heavy metals occur naturally in soil environment as a result of the weathering of parent materials depending on the mineral constituents in pedogenetic processes (Wuana and Okieimen, 2011; Kabata-Pendias and Pendias 2001; Pierzynski et al., 2000). Heavy metals are generally classified into trace and toxic metals. Trace metals are required in small or trace amounts for the regulation of internal processes and proper functioning of microorganisms, plants and other soil organisms while toxic metals when present, even in small quantities pose a threat to soil flora and fauna. In this study, trace metals such as zinc, manganese, copper, nickel and chromium were detected in very low concentrations in soil, while toxic metals such as cadmium, vanadium, lead, arsenic and mercury were below detection in soil, prior to contamination with crude oil. After contamination of soil, a significant amount of heavy metals was reported in soil, in concentration above national and international recommended guidelines for soil. This indicated that petroleum or crude oil is a major source of heavy metals pollution in polluted environment. Dickson and Udoessien (2012) on the studies of Nigeria's crude oil blends reported the presence of heavy metals such as zinc, lead, manganese, cobalt, cadmium, iron, nickel, chromium, copper and vanadium. They observed that the levels of lead, cadmium, chromium, manganese, zinc, copper and cobalt where low when compared to WHO (2011) recommended levels in the environment, but reported higher values for nickel, vanadium and iron. The values of heavy metals reported in our study were higher than those reported by Dickson and Udoessien (2012).

\section{Heavy Metals Bioremediation}

Heavy metals concentration in contaminated soil inoculated with earthworms showed a significant decreased after 90 days of the study, 
although there was a variation in the decreasing levels with each of the metals (Figure 2). Zinc decreased by $57.66 \%(20.62 \pm 0.01$ to $8.73 \pm 0.08)$, followed by manganese with $57.72 \%$ $(8.94 \pm 0.02$ to $3.78 \pm 0.04)$, copper $57.64 \% \quad(6.87 \pm 0.00$ to $2.91 \pm 0.03)$, nickel $57.69 \% \quad(10.81 \pm 0.00 \quad$ to
$4.57 \pm 0.04), \quad$ cadmium $\quad 57.57 \%$ (3.04 \pm 0.01 to $1.29 \pm 0.02)$, vanadium $57.68 \% \quad(5.60 \pm 0.00$ to $2.37 \pm 0.02)$, chromium $57.67 \% \quad(8.15 \pm 0.01$ to $3.45 \pm 0.03)$, lead $57.64 \%(4.91 \pm 0.00$ to $2.08 \pm 0.02)$, arsenic $1.36 \%(2.95 \pm 0.01$ to $2.91 \pm 0.03$ ) and mercury $57.41 \%$ (1.08 \pm 0.01 to $0.46 \pm 0.00$ ).

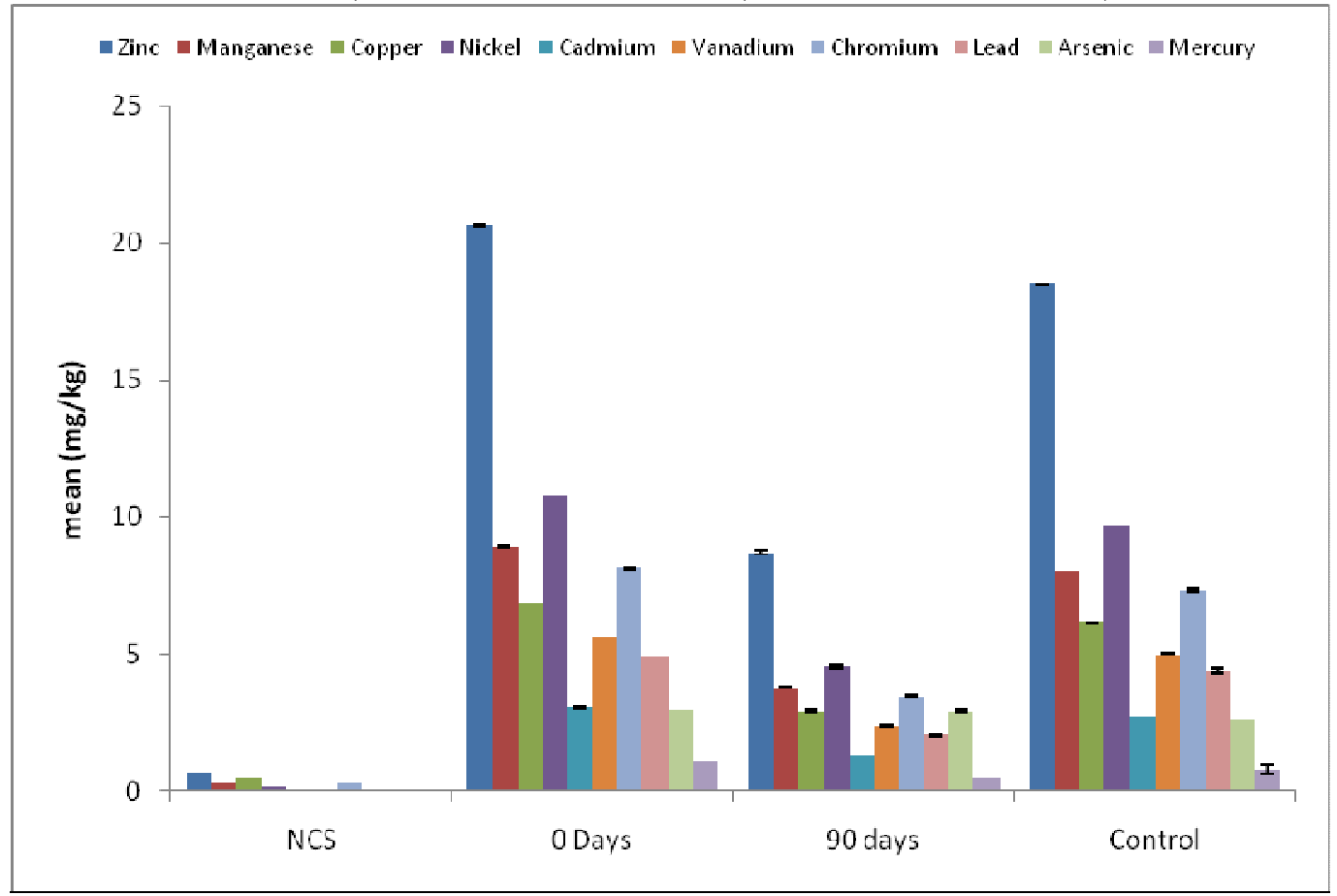

Figure 3: Heavy metals bioremediation in crude oil contaminated soil with $H$. africanus

All the heavy metals recorded a highly significantly decreased from the contaminated soil by the activities of $H$. africanus except arsenic which recorded a slight reduction in soil. This implies that the heavy metals were readily bioavilable for uptake by the earthworms as bioremediation of soil sets in. Several factors may be responsible for the uptake of metals from contaminated soil such as the soil properties, metal form and speciation and the origin of the metals into soil. The chemical form (species) in which a metal is found in the receiving environmental system may render it more bioavailable (D'Amore et al.,
2005) and heavy metals from anthropogenic sources tend to be more mobile and bioavailable than metal from pedogenic, or lithogenic sources (Wuana and Okieimen, 2011; Kuo et al., 1983; Kaasalainen and Yli-Halla, 2003). Assessment of the properties of the soil used for this study indicated that sand constituted the highest (96) percentage followed by silt (3) and clay (1), hence the soil can be referred to as sandy soil. Heavy metals bound less to sandy soil compared to silt and clay soil, making the metals more readily available for uptake by earthworms. Heavy metals are said to be mobile under acidic conditions. The $\mathrm{pH}$ 
recorded in this study which indicated the slightly acidic nature of the soil before and after contamination implies that the soil conditions may have influenced the mobility of metals thereby making the metals bioavailable for uptake by $H$. africanus.

On the effect of organic matter substrate on the toxicity of copper to Aporrectodea longa Ezemonye et al. (2006) reported that uptake increased as copper concentration increased in soil amended with organic substrates such as pig, poultry and cow manure. Iordache and Borza (2012) reported a decreasing trend for lead, manganese, copper and zinc with lumbricoid earthworms in Romania. Udovic and Leston (2007) reported very high values for zinc and lead with Lumbricus rubellus and Eisenia foetida in Slovenia. At the end of this study, all the heavy metals recorded about $57.63 \%$ removal from contaminated soil except arsenic which was $1.36 \%$. This indicated that substantial amount of heavy metals are still left in soil at the end of the study. It is possible that the earthworm has reached its uptake threshold for heavy metals or there was no sufficient time to have taken all the heavy metals from the polluted soil at the termination of the study. Sinha et al. (2009) reported that upon chemical analysis, the vermicomposted sludge was over $80 \%$ free of heavy metals such as cadmium and lead. Metals of interest in the study followed a similar bioremediation pattern except arsenic. While the other metals are decreasing with time, arsenic first decreased within the first 30 days, it increased in the next 60 days before it slightly decreased at the end of 90 days. The factors responsible for this unusual trend is not clear and appropriate inference are lacking but it may not be unconnected with the fact that the arsenic form present was not readily available for uptake by the earthworm species unlike the other metals. Again, being a very toxic metal, it is probable that the earthworms selectively responded against arsenic due to its toxicity in the contaminated environment.

There are concerns that earthworms can bioaccumulate and contaminate the food chain with pollutants including heavy metals taken from the environment. These concerns stem from the fact that heavy metals are not readily biodegradable and hence are recalcitrant in the environment. There are information that earthworms can bioremediate heavy metals through methylation, sequestration, growth dilution processes, while metallothionein (MT), a metal-binding protein has been reported with the potentials to detoxify heavy metals in earthworms (Langdon et al., 2001; Janssens et al., 2009). The presence of MT2 protein around blood vessels in the chloragogenous tissue of the earthworm, L. rubellus may play a role in the detoxification of heavy metals in earthworms (Langdon et al., 2001). Again, Veltman et al. (2007) indicated that from immunohistochemical observations, a significant proportion $(>70 \%)$ of $L$. rubellus cadmium concentration is sequestered by cysteine-rich metal-binding proteins, such as metallothionein. This could be the case for other Lumbricoid species for trace metals present in soil.

\section{Bioaccumulation Factor $(B A F)$}

In this study, the bioaccumulation factor was evaluated as the concentration of the heavy metals in the tissues of the earthworms in relation to the concentration in soil after 90 days of the experiment as indicated in the equation below; 
$\mathrm{BAF}_{\text {heavy metals }}=\frac{H M_{E}}{H M_{S}}$

where

$\mathrm{BAF}_{\text {heavy metals }}=$ bioaccumulation factor for heavy metals

$H M_{E} \quad=$ heavy metal concentration in earthworm $(\mathrm{mg} / \mathrm{kg})$

$H M_{S} \quad=$ heavy metal concentration in soil $(\mathrm{mg} / \mathrm{kg})$

The BAF showed that zinc, manganese, copper, cadmium, vanadium, chromium and lead had BAFs of 1.36 , while nickel, arsenic and mercury have BAFs of 1.37, 0.01 and 1.35 respectively. The higher the bioaccumulation factors for a specific contaminant, the more the uptake, nickel had the highest uptake by earthworms, arsenic had the lowest, while zinc, manganese, copper, cadmium, vanadium, chromium, lead and mercury had similar levels of uptake. Earthworms are thought to require some levels of trace metals for their proper biological function, but the preference for the uptake of trace metals and the fate of toxic metals by earthworms and particularly $H$. africanus remains unresolved. The level of trace element requirement and rate of bioremediation may influence the levels of uptake of heavy metals by earthworms (Ekperusi and Aigbodion, 2015). The BAF in our study were higher than that reported by Dai et al. (2004) on the heavy metal accumulation by two earthworm species for cadmium $>$ zinc $>$ copper $>$ lead respectively.

\section{Conclusion}

It is important that an effective bioremediation strategy be adopted in the removal of pollutants such as heavy metals from contaminated soil. The earthworm species, $H$. africanus in this study has shown a strong potential in the bioremediation of heavy metals from crude oil polluted soil. The earthworm was able to significantly reduce the levels of the metals in the crude oil polluted soil, although, the fate of the heavy metals in the earthworms still remains unknown. It can be concluded that the earthworm $H$. africanus can be use effectively to bioremediate heavy metals from moderately polluted soil with crude oil.

\section{References}

Ameh, A.O., Mohammed-Dabo, I.A., Ibrahim, S. and Ameh, J.B. (2013). Earthworm-assisted bioremediation of petroleum hydrocarbon contaminated soil from mechanic workshop. Afr. J. Env. Sc. Tech. 7(6): 531-539

Ameh, A.O., Mohammed-Dabo, I.A., Ibrahim, S., Ameh, J.B., Azienge, C.D. and Tanimu, Y. (2011). Earthworm survival in used engine oil contaminated soil spiked with manure. Int. J. Biol. Chem. Sci., 5(3): 923-929

Ameh, A.O., Mohammed-Dabo, I.A., Ibrahim, S., Ameh, J.B., Tanimu, Y. and Bello, T.K. (2012). Effect of earthworm inoculation on the bioremediation of used engine oil contaminated soil. Int. J. Biol. Chem. Sci. 6(1): 493-503

AOAC (2005). Methods of Analysis. Association of Official Analytical Chemists, 2005. Washington, D. C.

Azarpira H, Behdarvand P, Dhumal K (2013). Effect of different bulking materials and earthworms species on bioremediation potential of municipal sewage sludge. $J$ Environ Earth Sci., 3(12):68-72. 
Bruce, R.C. and Rayment, G.E. (1982). Analytical methods and interpretations used by the Agricultural Chemistry Branch for soil and land use surveys. DPI Bulletin QB82004. Department of Primary Industries, Brisbane, Queensland, Australia.

Ceccanti, B., Masciandaro, G., Garcia, C., Macci, C. and Doni, S. (2006). Soil bioremediation: Combination of earthworms and compost for the ecological remediation of a hydrocarbon polluted soil. Water Air Soil Pollut., 177: 383-397.

Cheng, J. and Wong, M.H. (2002). Effects of earthworms on $\mathrm{Zn}$ fractionation in soils. Biology and Fertility of Soils 36: $72-78$

Contreras-Ramos, S.M., Alvarez-Bernal, D. and Dendooven, L. (2006). Eisenia fetida increased removal of polycyclic aromatic hydrocarbons (PAHs) from Soil, Env. Pollut. 141: 396-401

D'Amore, J.J., Al-Abed, S.R., Scheckel, K.G. and Ryan, J.A. (2005). Methods for speciation of metals in soils: a review, Journal of Environmental Quality, 34(5): 17071745

Dai, J., Becquer, T., Rouiller, J.H., Reversata, G., Bernhard-Reversata, F., Nahmania, J., Laville, P. (2004). Heavy metal accumulation by two earthworm species and its relationship to total and DTPAextractable metals in soils, Soil Biology and Biochemistry 36: 91-98

Dickson, U.J. and Udoessien, E.I. (2012). Physicochemical studies of Nigeria's crude oil blends, Petroleum and Coal 54(3): 243-251

Edwards, C.A. and Arancon, N.Q. (2006). The science of vermiculture: the use of earthworms in organic waste management, Soil Ecology
Laboratory, The Ohio State University, Columbus, Ohio, U.S.A. 1-25pp

Ekperusi, O.A. and Aigbodion, I.F. (2015). Bioremediation of heavy metals and petroleum hydrocarbons in diesel contaminated soil with the earthworm: Eudrilus eugeniae, Springer Plus, 4: 540 doi:10.1186/s40064-015-1328-5

PMCID: PMC4579197

Ezemonye, L.I.N., Agbedia, C.U. and Illechie, I. (2006). The effect of organic matter on the toxicity of $\mathrm{Cu}$ to earthworms (Aporrectodea longa), Afri. J. Env. Pollut. Publ. Hlth. 5(1): 59-67

Hartenstein, R., Neuhauser, E.F., Collier, J. (1980). Accumulation of heavy metals in the earthworm Eisenia foetida. J. Environ. Qual. 9: 23-26

Heine, O. and Larink, O. (1993). Food and Cast Analyses as a Parameter of Turn-over of Materials by Earthworms (Lumbricus terrestris L), Pedobiologia 37(4): 245-256.

Hobbelen, P.H.F., Koolhaas, J.E. and van Gestel, C.A.M. (2006). Bioaccumulation of heavy metals in the earthworms Lumbricus rubbellus and Aporrecodea caliginosa in relation to total and available metal concentrations in field soil. Env. Pollut. 144: 639-646

Iordache, M.I. and Borza, I.N. (2010). Relation between chemical indices of soil and earthworm abundance under chemical fertilization. Plant Soil Environ. 56: 401-407.

Iordache, M.I. and Borza, I.N. (2012). Earthworms response (Oligochaeta: Lumbricidae) to the physical properties of soil under condition of organic fertilization Food, Agriculture and Environment 10(2): 1051-1055 
ISO 1993. ISO 11268-1: (1993). Soil quality - Effects of pollutants on earthworms (Eisenia fetida) - Part 1: Determination of acute toxicity using artificial soil substrate, International Organization for Standardization, ISO Central Secretariat, CP 56, CH1211, Geneva 20, Switzerland

Janssens, T.K.S., Roelofs, D. and van Straalen, N.M. (2009). Molecular mechanisms of heavy metal tolerance and evolution in invertebrates, Insect Science 16: 3$18 . \quad$ doi:10.1111/j.17447917.2009.00249.x

Kaasalainen, M. and Yli-Halla, M. (2003). Use of sequential extraction to assess metal partitioning in soils, Environmental Pollution, 126(2): 225-233

Kabata-Pendias, A. and Pendias, $\mathrm{H}$. (2001). Trace Metals in Soils and Plants, CRC Press, Boca Raton, Fla, USA, 2nd edition, 2001

Kuo, S., Heilman, P.E. and Baker, A.S. (1983). Distribution and forms of copper, zinc, cadmium, iron, and manganese in soils near a copper smelter, Soil Science, 135(2): 101109

Langdon, C.J., Piearce, T.G., Meharg, A.A. and Semple, K.T. (2001). Survival and behaviour of the earthworms Lumbricus rubellus and Dendrodrilus rubidus from arsenatecontaminated and non-contaminated sites, Soil Biol. Biochem. 33: 12391244

Lui, Y. (2012). Bioavailability of cadmium and zinc to two earthworm species in high-metal soils, PhD. Thesis, Graduate Program in Soil and Water Sciences, University of California, Riverside, United States

Manyuchi, M.M. Chitambwe, T., Muredzi, P. and Kanhukamwe, Q. (2013). Continuous flow-through vermireactor for medium scale vermicomposting, Asian J. Eng. Tech. 1(1): 44-48

Marinussen, M.P.J.C., Vander Zee, S.E.A.T.M., De Haan, F.A.M., Bouwman, L.M. and Hefting, M., (1997). Heavy metal (copper, lead and zinc) accumulation and excretion by the earthworm, Dendrobaena veneta. J. Env. Qua. 26: 278-284

Miroslav, R. and Vladimir, N.B. (1999). Practical Environmental Analysis, Royal Society of Chemistry. UK.

Morgan, J.E. and Morgan, A.J. (1999). The accumulation of metals $(\mathrm{Cd}, \mathrm{Cu}$, $\mathrm{Pb}, \mathrm{Zn}$ and $\mathrm{Ca}$ ) by two ecologically contrasting earthworm species (Lumbricus rubellus and Aporrectodea caliginosa): implications for ecotoxicological testing. Appl. Soil Ecol. 13: 9-20

Owa, S.O., Dedeke, G.A., Morafa, S.O.A. and Yeye, J.A. (2003). Abundance of earthworms in Nigerian ecological zones: implications for sustaining fertilizer-free soil fertility. Afri. Zoo. 38(2): 235-244

Peijnenburg, W.J.G.M., Posthuma, L., Zweers, P.G.P.C., Baerselman, R., de Groot, A.C., Van Veen R.P.C. and Jager, D.T. (1999). Prediction of metal bioavailability in Dutch field soils for the oligochaete Enchytraeus crypticus. Ecotoxicol. Environ. Saf. 43: 170-186

Pierzynski, G.G., Sims, J.T. and Vance, G.F. (2000). Soils and Environmental Quality, CRC Press, London, UK, 2nd edition, 2000

Sandor, M., and Schrader, S. (2012). Interaction of earthworms and enchytraeids in organically amended soil. North-Western J Zoo 8(1):4656

Satchell, J.E. (1983). Earthworm EcologyFrom Darwin to Vermiculture, 
Chapman and Hall Ltd., Cambridge, London. 1-178pp

Schaefer, M. and Filser, J. (2007). The influence of earthworms and organic additives on the biodegradation of oil contaminated soil, Applied Soil Ecology 36: 53-62

Sinha, R.K., Gokul, B. and David, R. (2008). Converting wasteland into wonderland by earthworms: A lowcost nature's technology for soil remediation: A case study of vermiremediation of $\mathrm{PAH}$ contaminated soil, The Environmentalist; UK; 28: 466-475

Sinha, R.K., Sunil, H., Gokul, B., Swapnil, P., Bapat, P.D., Kunal, C. and Dalsukh, V. (2009). Vermiculture Biotechnology: The Emerging Costeffective and Sustainable Technology of the 21st Century for Multiple Uses from Waste and Land Management to Safe and Sustained Food Production, Environmental Research Journal, 3(1): 41-110. NOVA Svience Publishers, NY, USA

Sinha, R.K., Herat, S. and Valani, D. (2010). Earthworms - The Environmental Engineers: Review of Vermiculture Technologies for Environmental Management \& Resource Development, Int. J. of Environmental Engineering, In Rajiv K Sinha, Sunil Herat \& Sunita Agarwal (Eds.) Special Issue on 'Vermiculture Technology for Environmental Management and Resource Development, X: 1-35

Suthar, S., Singh, S. and Dhawan, S. (2008). Earthworms as bioindicator of metals ( $\mathrm{Zn}, \mathrm{Fe}, \mathrm{Cu}, \mathrm{PB}$ and $\mathrm{Cd})$ in soils: Is metal bioaccumulation affected by their ecological category? Ecol. Eng. 32: 99-107
Udovic, M. and Lestan, D. (2007). The effect of earthworms on the fractionation and bioavailability of heavy metals before and after soil remediation. Env. Pollut. 148: 663668

USEPA (2010). Solid waste and emergency response glossary, Bioaccumulation: United States Environmental Protection Agency. Available http://www.epa.gov/oswer/riskassess ment/glossary.htm\#b Accessed $15 / 10 / 2015$

Veltman, K., Huijbregts, M.A.J., Vijver, M.G., Peijnenburg, W.J.G.M., Hobbelen, P.H.F., Koolhaas, J.E. van Gestel, C.A.M, van Vliet, P.C.J. and Hendriks, A.J. (2007). Metal accumulation in the earthworm Lumbricus rubellus. Model predictions compared to field data. Environmental Pollution, 146: 428436

Wuana, R.A. and Okieimen, F.E. (2011). Heavy Metals in Contaminated Soils: A Review of Sources, Chemistry, Risks and Best Available Strategies for Remediation, ISRN Ecology, 120

Zavala-Cruz, J. Trujillo-Capistran, F. Ortiz-Ceballos, G.C. and OrtizCeballos, A.I. (2013). Tropical Endogeic Earthworm Population in a Pollution Gradient with Weathered Crude Oil. Res. J. Env. Sc. 7: 15-26. DOI: 10.3923/rjes.2013.15.26

Zorn, M.I., Van Gestel, C.A.M., Eijsackers, H. (2004). The effect of two endogeic earthworm species on zinc distribution and availability in artificial soil columns. Soil Biol. Biochem 37: 917-925. 